\title{
KOMUNIKASI LEMAH LEMBUT DALAM STUDI HADITS
}

\author{
Hanif M. Dahlan \\ STAIN Tengku Dirundeng Meulaboh \\ E-mail: hanifmdahlan@staindirundeng.ac.id
}

\begin{abstract}
Abstrak
Sifat lemah lembut memiliki keutamaan yang menghiasi tutur sapa dan tindakan sehingga dapat mendatangkan kebaikan dan pahala. Tujuan penulisan artikel ini untuk mendeskripsikan keutamaan lemah lembut terhadap sesama manusia dan hewan berdasarkan ajaran Islam dalam konteks kajian hadits. Penulisan artikel ini menggunakan menggunakan pendekatan penelitian kepustakaan (library research). Teknik pengumpulan data dilakukan dengan cara menghimpun data tentang komunikasi lemah lembut yang bersumber dari al-Quran, hadist, tafsir, jurnal dan buku yang relevan. Data yang terkumpul dari berbagai literatur dianalisis dan ditelaah sehingga menemukan suatu kesimpulan tentang konsep komunikasi lemah lembut dalam konteks kajian hadits. Sifat lemah lembut sangat penting diterapkan dalam kehidupan sehari-hari baik kepada manusia maupun kepada hewan. Lemah lembut sangat dianjurkan dalam pergaulan walaupun kepada orang yang tidak berbuat baik kepada kita. Penerapan sikap lemah lembut dalam kehidupan akan terciptanya persatuan dan kesatuan, mencegah terjadinya perpecahan dan permusuhan dan terjalinnya hubungan yang harmonis sehingga mengarah pada terciptanya perdamaian dan integrasi sosial berdasarkan nilai-nilai Islam.
\end{abstract}

Kata kunci: Komunikasi, Lemah Lembut, Manusia, Hewan, dan Hadits.

\begin{abstract}
Gentleness has the virtues that adorn greetings and actions so that it can bring good and reward. The purpose of writing this article is to describe the virtues of gentleness towards fellow humans and animals based on Islamic teachings in the context of hadith studies. The writing of this article uses a library research approach. Data collection techniques are carried out by collecting data about meek communication sourced from the Koran, hadiths, commentaries, journals and relevant books. Data collected from various literatures are analyzed and analyzed so as to find a conclusion about the concept of meek communication in the context of hadith studies. Meek nature is very important to be applied in daily life both for humans and animals. Meekness is highly recommended in relationships even with people who do not do good to us. The application of a meek attitude in life will create unity and unity, prevent division and hostility and the establishment of harmonious relationships that lead to the creation of peace and social integration based on Islamic values.
\end{abstract}

Keywords: Communication, Gentle, Human, Animal, and Hadith. 


\section{PENDAHULUAN}

Manusia merupakan makhluk sosial yang tidak bisa hidup sendiri dan selalu membutuhkan bantuan orang lain dalam menjalankan aktifitas dan kehidupannya. Interaksi antara manusia dengan manusia lainnya melalui proses komunikasi. ${ }^{1}$ Komunikasi berhubungan dengan perilaku manusia dan kepuasan terpenuhinya kebutuhan berinteraksi dengan manusia lain. ${ }^{2}$ Manusia berinteraksi dengan manusia lainnya untuk menghasilkan pergaulan hidup dalam suatu kelompok sosial. Pergaulan hidup manusia akan tercipta apabila seseorang atau sekelompok orang yang saling berinteraksi, bekerja sama, saling berkomunikasi untuk mencapai tujuan bersama. ${ }^{3}$

Komunikasi yang baik dan efektif akan berdampak pada terciptanya hubungan yang baik, koordinasi yang baik, dan tersampainya informasi dengan baik. Komunikasi merupakan suatu usaha seseorang untuk memberikan pengertian, menyampaikan informasi atau pesan kepada orang lain. Komunikasi adalah proses mengirimkan pesan, menyampaikan pesan, pemilihan sarana atau media, penerimaan pesan, respon efek atau pengaruh untuk mengubah sikap, perilaku atau pendapat baik secara lisan ataupun melalui media. ${ }^{4}$

Manusia harus memiliki etika berkomunikasi yang baik sesuai ajaran alQuran sehingga membawa manfaat bagi dirinya dan manusia lainnya. ${ }^{5}$ Sebagai seorang muslim, sudah sepatutnya mengimplementasikan etika yang baik dalam berkomunikasi yang sesuai dengan ajaran agama Islam. Komunikasi dalam agama Islam adalah komunikasi yang berakhlaqul karimah, yakni komunikasi yang bersumber pada al-Quran dan hadis.

Salah satu pola komunikasi yang diajarkan oleh rasulullah adalah komunikasi lemah lembut. Diantara bentuk komunikasi lemah lembut adalah

\footnotetext{
${ }^{1}$ Mujahidah, Mujahidah. Urgensi Komunikasi Dalam Kelompok. Al-Mishbah: Jurnal Ilmu Dakwah dan Komunikasi, 8, no. 2 (2012): 293-310

2 Bahtar, Bahtar. "Komunikasi Anti Kekerasan: Membangun Budaya Damai dalam Perspektif Etika Komunikasi Islam." Al-Mishbah: Jurnal Ilmu Dakwah dan Komunikasi 9, no. 1 (2015): 27-44.

${ }^{3}$ Elly, M. Setiadi, dkk, Ilmu sosial dan Budaya Dasar, (Jakarta: Kencana Penanda Media Group, 2007). Hal. 90. Hal. 18 .

${ }^{4}$ Onong Uchjana Efendi. Dinamika Komunikasi. (Bandung: Remaja Rosdakarya, 1992).

${ }^{5}$ Muslimah, Muslimah. "Etika Komunikasi dalam Persfektif Islam." Sosial Budaya 13, no. 2 (2017): 115-125.
} 
berbicara yang sopan, bersikap dengan santun, menahan diri untuk tidak membalas perlakuan buruk orang lain, bahkan tetap membalas setiap keburukan dengan kebaikan.

Pola komunikasi lemah lembut sangat dibutuhkan dalam ajaran agama Islam untuk menyebarkan kebaikan dan nilai-nilai Islam kepada manusia sehingga terhindar dari konflik sosial dalam kehidupan beragama, berbangsa dan bernegara. Internalisasi pola komunikasi islami pada akhirnya akan mengarah pada terciptanya perdamaian dan integrasi sosial berdasarkan nilai-nilai Islam. ${ }^{6}$

Pola komunikasi lemah lembut dapat dijadikan sebagai landasan bagi setiap muslim ketika melakukan komunikasi, baik dalam berdakwah, dalam pergaulan sehari-hari maupun dalam aktifitas lainnya. Penerapan komunikasi lemah lembut dapat berdampak pada terjalinnya hubungan yang harmonis dalam kehidupan, dapat membangun komunitas sosial yang damai, aman dan tenteram sehingga terwujudnya peradaban manusia yang tinggi.

Fenomena yang terjadi pada kehidupan selama ini, masih menemukan motif kekerasan dalam berkomunikasi, seperti karakter kasar, emosional, kasar, anarkis, dan perkataan lainnya yang dapat memunculkan permusuhan di masyarakat. ${ }^{7}$ Ceramah di beberapa daerah yang disampiakan oleh da'i yang keras dapat memunculkan beberapa permasalahan pada masyarakat. Pemahaman tentang dakwah tidak bisa disampaikan secara lembut namun harus ada hentakan akan mengarahkan masyarakat pada pemikiran bahwa Islam disebarkan dengan kekerasan dan paksaan. ${ }^{8}$

Selama ini manusia menggunakan media sebagai alat berkomunikasi. Berbagai bentuk media dirancang untuk memudahkan masuai berkomunikasi melalui media soail, seperti facebook, instagram, twitter, whatsapp, blog, dan lainnya. Dalam konteks komunikasi dakwah, berkomunikasi melalui media sosial

${ }^{6}$ Malla, Hamlan Andi Baso. "Urgensi Komunikasi Pendidikan Islam Dalam Membangun Pendidikan Harmoni Pasca Konflik Masyarakat." Al-Mishbah: Jurnal Ilmu Dakwah dan Komunikasi 10, no. 1 (2014): 109-120.

7 Bahtar, Bahtar. "Komunikasi Anti Kekerasan: Membangun Budaya Damai dalam Perspektif Etika Komunikasi Islam." Al-Mishbah: Jurnal Ilmu Dakwah dan Komunikasi 9, no. 1 (2015): 27-44.

${ }^{8}$ Bahrisy, Ahmad. Konsep kelembutan dakwah dalam al-quran, 2018. Undergraduate thesis, UIN Sunan Ampel Surabaya. 
sangat memungkinkan untuk saling propaganda. ${ }^{9}$ Oleh karena itu, dalam berkomunikasi perlu menanamkan nilai-nilai karakter keagamaan, lemah lembut, saling menghormati, kepdulian sosial, saling memotivasi, menghasilkan sikap jujur, kreatif dan tanggung jawab. ${ }^{10}$

Berdasarkan uraian permasalahan di atas, maka tujuan penulisan ini untuk menjelaskan dan mendiskripsikan pesan dan pola komunikasi lemah lembut dalam pandangan Islam. Artikel ini diharapkan dapat bermanfaat bagi seluruh pembaca dalam memahami dan menerapkan komunikasi lemah lembut dalam kehidupan sehari-hari sehingga terciptakan suasana kehidupan yang aman, tentram dan damai.

\section{LANDASAN TEORI}

\section{Pengertian lemah lembut}

Lemah lembut dalam Bahasa Arab sering dikenal dengan istilah Ar-Rifq ${ }^{11}$, Al-Lin ${ }^{12}$, Al-Hilmu ${ }^{13}$, Al-Luthf ${ }^{4}$ yang memiliki arti yang sama. Al-luthfu adalah dasar kata dari Al-Lathif yang merupakan salah satu dari nama Asmaul husna yang bermakna Maha lemah lembut ${ }^{15}$. Ibnu Hajar Al-Asqalani memberikan pengertian tentang Ar-Rifq sebagai sisi lunak seseorang baik perbuatan atau perkataan dan melakukan sesuatu dengan cara yang paling mudah. Lawan kata lemah lembut adalah sifat kasar. ${ }^{16}$

Berdasarkan penjelasana di atas, maka dapat disimpulkan bahwa lemah lebut adalah sikap seseorang dalam menyikapi sesuatu dengan santai tanpa terburuburu dan melaksanakan kegiatan tersebut dengan cara yang paling mudah. Lemah lembut dapat diterapkan pada perkataan dan perbuatan seseorang dalam berinteraksi dengan sesame manusia dalam kehidupan. Contoh lemah lembut di

9 Suharto, Suharto. "Komunikasi Dakwah: Interaksi Dan Integrasi Media Sosial." AlMishbah: Jurnal Ilmu Dakwah dan Komunikasi 9, no. 1 (2013): 89-100.

10 Malla, Hamlan Andi Baso. "Implementation Of Madrasah Head Leadership Communication In The Development Of Religious Characters." Al-Mishbah: Jurnal Ilmu Dakwah dan Komunikasi 15, no. 2 (2020): 147-162.

11 Muhammad Bin Abi Bakri Bin Abdul Qadir Ar-Razi, Mukhtarus shihah, (Bairut, Maktabat Lubnan, 1989). Hal: 220.

12 Ibid., Hal: 538.

13 Ibid., Hal: 133.

${ }^{14}$ Ibid., Hal: 526.

${ }^{15}$ Abdul Karim Al-Qusyairi, Syarah Asmaul Husna, (Bairut, Darul Azal, 1987). Hal. 137

${ }^{16}$ Ibnu Hajar Al-Asqalaqi, Fathul Baari, Juz 13, (Riyadh, Darul Thayyibah, 2005). Hal. 572. 
antaranya; berkomunikasi lemah lembut antara anak dengan orang tua, murid dengan guru, yang muda dengan yang lebih tua, tidak berkata kasar walaupun kepada orang lain yang melakukan kesalahan, bersikap baik dan tidak balas dendam kepada orang lain yang telah berbuat kasar kepada kita.

\section{Pentingnya lemah lembut}

Lemah lembut merupakan salah satu sikap akhlakul karimah yang memiliki banyak keutamaan. Seseorang yang memiliki akhlak yang mulia akan terpancar sikap dan perilaku yang baik, terpuji dan banyak membawa manfaat dari dirinya. Persoalan apapun dalam kehidupan di masyarakat baik persoalan pribadi, keluarga, tetangga, masyarakat dan negara jika diselesaikan dengan sikap dan perbuatan terpuji maka persoalan tersebut akan dapat diselesaikan dengan baik. ${ }^{17}$

Salah satu sifat akhlakul karimah dalam Islam adalah sifat lemah lembut. Al-Quran dan hadits menerangkan banyak hal tentang keutamaan lemah lembut, di antaranya Allah berfirman dalam Al-quran:

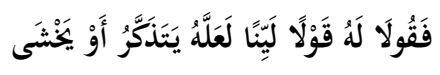

Artinya: "Maka berbicaralah engkau berdua kepadanya (Fir'aun) dengan kata-kata yang lemah lembut, mudah-mudahan dia sadar dan takut". ${ }^{18}$

Ayat di atas menjelaskan pesan Allah swt kepada nabi Musa dan Harun untuk tetap bersikap lemah lembut dan memberikan nasehat walaupun berhadapan dengan fir'aun yang telah melampau batas. Allah swt memerintah bersikap lemah lembut kepada Fir'un yang secara telah mempersukutukan Allah dan melakukan banyak kedhaliman, apalagi kepada orang yang tidak bersalah. Hikmah berkomunikasi dengan lemah lembut diharapkan dapat memberikan rasa nyaman kepada orang lain sehingga orang tersebut lebih mudah untuk menerima informasi, pesan, seruan dan saran yang ingin disampaikan.

Keutamaan sifat lemah lembut juga terdapat dalam banyak kitab-kitab hadits. Hampir tidak ditemukan sebuah kitab hadits kecuali penulisnya menyusun satu bab khusus tentang keutamaan lemah lembut. Imam muslim dalam kitabnya

${ }^{17}$ Tim Dosen Pendidikan Agama Islam Universitas Lampung, Pendidikan Agama Islam Berbasis Karakter Di Perguruan Tinggi, (Jakarta: Rajawali Pres, 2014). Hal. 140

${ }^{18}$ QS. Thaha: 44. 
shahih muslim menuliskan bab keutamaan lemah lembut secara khusus yang merangkum beberapa hadits lemah lembut, di antaranya:

$$
\text { عن جرير عن النبى -صلى الله عليه وسلم- قال 》 من يحرم الرفق يحرم الخير «. }
$$

Artinya: Dari jarir dari nabi shallahu alaihi wasallam bersabda: barang siapa yang dijauhkan dari sifat lemah lembut, berarti dia dijauhkan dari kebaikan. ${ }^{19}$

$$
\begin{aligned}
& \text { عن عائشة زوج النبى -صلى الله عليه وسلم- عن النبى -صلى الله عليه وسلم- قال 》 إن الرفق } \\
& \text { لا يكون فى شىء إلا زانه و لا ينزع من شىء إلا شانه «. }
\end{aligned}
$$

Artinya: Dari Aisyah isteri nabi shallahu alaihi wasallam dari nabi shallahu alaihi wasallam bersabda: Sesungguhnya lemah lembut itu tidak akan berada pada sesuatu melainkan ia akan menghiasinya (dengan kebaikan) sebaliknya, jika lemah lembut itu dicabut dari sesuatu melaikan ia akan membuatnya menjadi buruk. ${ }^{20}$

عن عائشة زوج النبى صلى الله عليه وسلم أن رسول الله صلى الله عليه وسلم قال ال يا عائشة إن الله رفيق يحب الرفق ويعطى على الرفق ما لا يعطى على العنف وما لا يعطى على ما

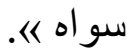

Artinya: Dari aisyah isteri nabi shallahu alaihi wasallam dari nabi shallahu alaihi wasallam bersabda: wahai Aisyah sesungguhnya Allah itu maha lembut. Dia mencintai kelembutan dan Allah memberikan pada sifat lemah lembut sesuatu yang tidak dia berikan pada sikap yang kasar dan juga tidak diberikan kepada sifat selain itu. ${ }^{21}$

Beberapa hadits di atas menjelaskan bahwa Allah swt memiliki dan mencintai sifat lemah lembut serta memerintahkan kepada kita untuk memiliki dan menerapkan sifat lemah lembut tersebut dalam kehidupan. Sikap lemah lembut merupakan pangkal suatu kebaikan yang akan mendatangkan kebaikan-kebaikan lainnya. Perbuatan yang baik akan menjadi kurang bermanfaat bagi sesorang apabila tidak diiringi dengan sikap lemah lembut. Contohnya; seorang guru yang menasehati muridnya dengan perkataan kasar dan menyakiti hati, maka nasehat tersebut akan sulit diterima oleh mereka.

19 Imam Muslim, Al-Musnad As-shahih, kitab Al-birri wa As-shillah wal Adab, bab fadhlurrifqi, juz 2, hadits no.2592, (Riyadh: Darul Thayyibah, 2006). Hal.1202.

${ }_{20}$ Imam Muslim, Al-Musnad As-shahih, kitab Al-birri wa As-shillah wal Adab, bab fadhlurrifqi, juz 2, hadits no.2594, Hal.1203.

21 Imam Muslim, Al-Musnad As-shahih, kitab Al-birri wa As-shillah wal Adab, bab fadhlurrifqi, juz 2, hadits no.2593, Hal.1203. 
Imam An-Nawawi memberikan penjelasan tentang beberapa keutamaan sifat lemah lembut. Keutamaan tersebut di antaranya; sikap lemah lembut dapat diterapkan dalam bersikap, kasar merupakan sifat tercela, kelembutan dapat mendatangkan kebaikan, kelembuatan akan diberikan pahala oleh Allah swt, serta lemah lembut merupakan salah satu sifat Allah swt. ${ }^{22}$

\section{Dampak mengambaikan sifat lemah lembut}

Sifat lemah lembut sangat banyak manfaat dan keutamaan bagi siapa saja yang mengamalkannya. Mengabaikan sifat lemah lembut berarti mengabaikan kebaikan yang akan diperolah dengan sifat tersebut. Hal ini akan mengakibatkan terjadinya kerugian bagi dirinya. Sifat kasar dalam bahasa arab disebut $A l$ - $U n f$ (العنف). Rasul shallahu alaihi wasallam menganjurkan kepada kita untuk menjauhi sifat kasar. Hal ini sesuai dengan hadits nabi Muhammada saw sebagai berikut:

$$
\begin{aligned}
& \text { عن عائشة رضي الله عنها : أن اليهود أتوا النبي صلى الله عليه و سلم فقالوا السام عليك قال } \\
& \text { ( و عليكم ) فقالت عائشة السام عليكم ولعنكم الله و غضب عليكم فقال رسول الله صلى الله عليه } \\
& \text { و سلم ( مهلا يا عائشة عليك بالرفق و إيالك و العنف أو الفحش ) . قالت أولم تسمع ما قالو ؟ } \\
& \text { قال ( أو لم تسمعي ما قلت رددت عليهم فيستجاب لي فيهم ولا يستجاب لهم في ) }
\end{aligned}
$$

Artinya: Dari aisyah radhiallahu 'anha bahwa sekelompok yahudi datang kepada nabi shallahu alaihi wasallam sambal berkata: "kebinasaan atasmu". Maka aisyah berkata: "Semoga atas kalian juga dan semoga laknat dan kemurkaan Allah kepada kalian". Beliau bersabda: "tenanglah wahai aisyah, berlemah lembutlah dan jangan kamu berkata keji”. Aisyah berkata: "apakah anda tidak mendengar apa yang mereka katakana? Beliau bersabda: "tidakkah engkau mendengar apa yang aku ucapkan, saya telah membalasnya, Adapun jawabanku akan dikabulkan sementara doa mereka tidak akan dikabulkan. ${ }^{23}$

Hadits di atas menegaskan bahwa nabi Muhammad shallahu alaihi wasallam menganjurkan kepada kita untuk bersikap lemah lembut dan menghindari sifat kasar dan perkataan kotor dalam berbagai situasi dan kondisi. Sikap lemah

\footnotetext{
${ }^{22}$ An-Nawawi, syarah shahih muslim, juz 4, (kairo, maktabah shafa, 2003) Hal. 138

${ }^{23}$ Imam Bukhari, Al-Jami' Ash-Shahih, juz:4, kitab Al-Adab, bab lam yakun nabi shallahu
} alaihi wasallam fahisyan wala mutafahisyan, hadits no: 6030 (kairo, maktabah salafiah, 1400H) Hal:96. 
lembut dianjurkan supaya tetap diterapkan kepada orang yang berbuat kasar kepada kita bahkan membalas keburukan seseorang dengan kabaikan.

Membalas keburukan dengan keburukan merupakan sifat tercela dan dilarang oleh Allah swt. Dampak mengabaikan sifat lemah lembut di antaranya; terputusnya silaturrahmi, memecahkan persatuan dan kesatuan, menyakiti hati orang lain, munculnya sifat marah dan dendam, menimbulkan permusuhan, dan lain sebagainya. Oleh karena itu, bagi setiap muslim perlu menerapkan sifat lemah lembut dalam menjalin hubungan dengan sesama ummat (hablum minan nas).

\section{METODE PENELITIAN}

Penelitian ini menggunakan pendekatan penelitian kualitatif. Penelitian kualitatif adalah suatu penelitian yang dilakukan untuk mengungkapkan dan mendeskripsikan serta menganalisis fenomena, peristiwa, kejadian, sikap, aktivutas sosial, kepercayaan, persepsi, serta pemahaman orang atau sekelompok orang yang dilakukan secara holistik. ${ }^{24}$ Dengan demikian, penelitian ini dilakukan untuk mendeskripsikan tentang pola komunikasi lemah lembut berdasarkan ajaran agama Islam dalam bentuk narasi secara mendalam dan penulis sebagai instrumen kunci.

Penelitin kualitatif ini termasuk jenis penelitian kepustakaan (library research). Penelitian kepustakaan (library research) adalah penelitian yang pengumpulan datanya dilakukan dengan menelaah berbagai literatur yang sesuai dengan fokus penelitian. ${ }^{25}$ Teknik pengumpulan data dilakukan dengan cara menghimpun data tentang pola komunikasi lemah lembut yang bersumber dari alQuran, hadist, tafsir, jurnal dan buku yang relevan. Data yang terkumpul dari berbagai literatur dianalisis dan ditelaah sehingga menemukan suatu kesimpulan tentang pola dan konsep komunikasi lemah lembut menurut ajaran agama Islam.

\section{HASIL DAN PEMBAHASAN}

Sifat lemah lembut merupakan salah satu sifat terpuji yang perlu diterapkan dalam kehidupan bermasyarakat. Penerapan sifat lemah lembut dalam kehidupan

24 Nana Syaodih Sukmadinata, Metode Penelitian Pendidikan, (Bandung: Remaja Rosdakarya, 2007). Hal. 60.

${ }^{25}$ Sarjono. DD., Panduan Penulisan Skripsi, (Yogyakarta : Jurusan Pendidikan Agama Islam, 2008). Hal.20. 
sehari-hari dapat mendatangkan kebaikan dan pahala di antara sesama manusia. Contoh sifat lemah lembut dalam kehidupan di antaranya adalah tidak menyakiti hati orang lain ketika berkomunikasi dan bersikap, berbicara dengan sopan, bertindak dengan santun, membalas kebaikan dengan kebaikan serta membalas kebururkan dengan kebaikan.

Sifat lemah lembut tidak hanya dapat diterapkan kepada orang yang berbuat baik kepada kita. Namun, sifat lemah lembut juga dianjurkan kepada orang yang berbuat kasalahan kepada kita. Islam mengajarkan kepada umat muslim supaya menebarkan kebaikan di seluruh dunia dan kepada siapapun. Hal ini sesuai dengan sabda nabi Muhammad saw sebagai berikut.

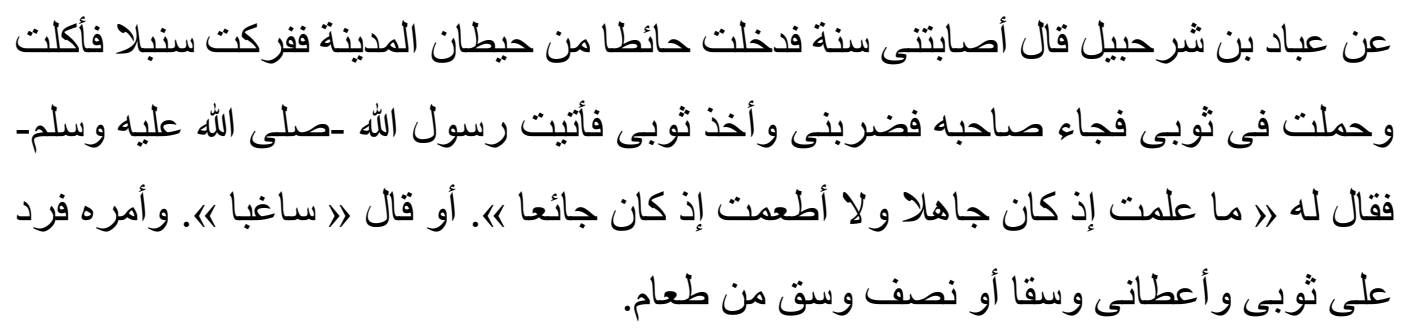

Artinya: Dari 'abbad bin syurahbil ia berkata: aku mengalami kelaparan. Kemudian aku memasuki kebun Madinah lalu aku mencabut tangkai lalu memakan buahnya dan aku membawa dalam bajuku. Kemudian pemilik kebun tersebut datang dan memukulku serta mengambil bajuku. Kemudian aku datang menjumpai rasulullah shallallahu alaihi wasallam lalu beliau berkata kepada pemilik kebun tersebut: engkau tidak mengajarinya tatkala dia tidak mengetahuinya, dan engkau tidak memberinya lapar tatkala dia lapar. $^{26}$

Hadits di atas menegaskan bahwa seorang muslim dituntut untuk bersikap lemah lembut kepada orang yang berbuat tidak baik kepada dirinya. Banyak orang dalam kehidupan sehari-hari membalas keburukan dengan keburukan tanpa memperhatikan sebab seseorang melakukan suatu kesalahan. Kadang kala seseorang melakukan kesalahan dalam keadaaan terpaksa. Hal ini dapat dilihat dalam hadits di atas nabi Muhammad shallallahu alaihi wasallam mempertanyakan sikap kasar pemilik kebun tersebut. Pelajaran yang dapat diambil dari hadits di atas adalah hendaknya seorang muslim lebih santun dan lemah lembut dalam menyikapi

${ }^{26}$ Abu daud, Sunan Abu Daud, kitab Jihad, bab fi ibni sabil ya'kul tamar.., juz 3, hadits No. 2620. (Bairut, Dar Ibnu Hazam, 1998). Hal. 64. 
suatu kejadian atau permasalahan. Kemudian diikuti dengan mencari informasi dan penjelasan tentang sebab terjadinya suatu permasalahan.

Nabi Muhammad shallallahu alaihi wasallam juga bersikap lemah lembut terhadap orang yang kencing di dalam masjid. Sebagaimana hadits nabi Muhammad saw berikut ini.

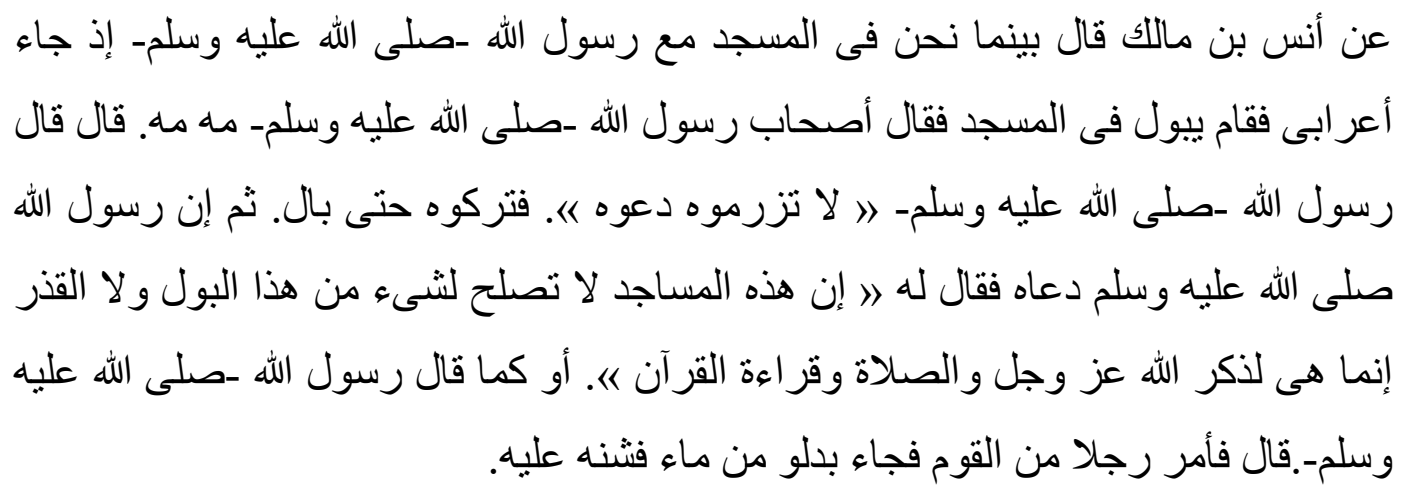

Artinya: Anas bin malik berkata: Ketika kami berada di masjid Bersama Rasulullah shallahu alaihi wasallam, tiba tiba seorang badui datang dan kencing di masjid. Maka para sahabatpun berkata: tahan, tahan. Lalu rasulullah shallahahu alaihi wasallam bersabda: janganlah kalian menghentikan kencingnya, biarlah hingga selesai kencing. Kemudian rasulullah shallahhalu alaihi wasallam memanggilnya seraya bersabda: sesungguhnya masjid ini tidak layak dikotori dengan air kencing atau kotoran lainnya. Masjid hanyalah untuk berzikir kepada Allah, shalat, dan membaca Al-Quran. Atau sebagaimana yang dikatakan Rasulullah shallahu alaihi wasallam lalu anas melanjutkan ucapannya lalu beliau memerintahkan seorang sahabat untuk mengambil seember air dan mengguyurnya. ${ }^{27}$

Hadits di atas menunjukkan bahwa rasulullah shallahu alaihi wasallam menyikapi suatu permasalah dengan lemah lembut dan bijaksana. Semua manusia mengalami permasalahan dalam kehidupannya masing-masing. Setiap permasalahan yang dihadapi perlu dicarikan solusi sebagai keputusan yang harus dilakukan. Tidak bijaksana dalam mengambil keputusan akan berakibat pada ketidakadilan, pertikaian, kekeliruan, penyesalan dan lain sebagainya.

Agama Islam mengajarkan kepada manusia supaya sifat lemah lembut tidak hanya dilakukan pada sesama manusia, akan tetapi juga kepada hewan. Allah swt telah menciptakan makhluk lain di dunia seperti hewan yang dapat digunakan untuk

${ }^{27}$ Imam Muslim, Shahih Muslim, kitab thaharah, bab wujub ghuslil baul..., juz 1, hadits No. 285, Hal. 144. 
memenuhi kebutuhan manusia. Agama Islam sangat peduli dan memerintahkan supaya berbuat baik terhadap hewan. Hal ini sesuai dengan sabda nabi Muhammad shallahu alaihi wasallam berikut ini.

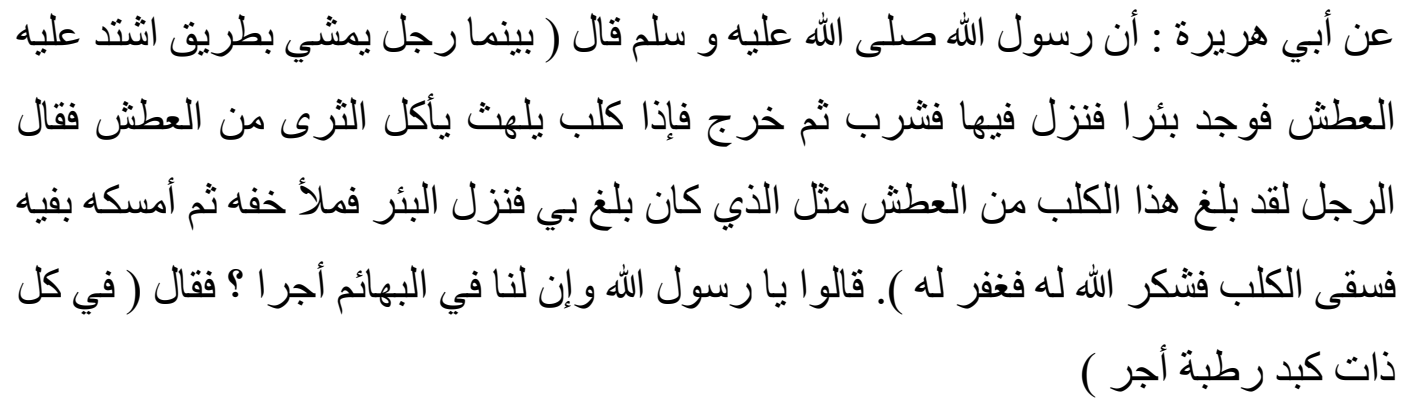

Artinya: Dari abu Hurairah bahwa rasul shallahu alaihi wasallam bersabda: pada suatu Ketika ada seorang laki laki sedang berjalan lalu dia merasa sangat kehausan. Kebetulan dia menemukan sebuah sumur, maka dia turun ke sumur untuk minum. Setelah keluar dari sumur, dia melihat seekor anjing menjulurkan lidahnya menjilat jilat tanah karena kehausan. Orang itu berkata: alangkah hausnya anjing itu seperti yang baru aku alami. Lalu dia turun Kembali ke sumur, kemudian mengambil air dengan sepatunya lalu menahan dengan mulutnya untuk dibawa kepermukaan sumur lalu memberi anjing itu minum. Maka Allah berterima kasih padanya dan mengampunkan dosanya. Para sahabat bertanya: wahai rasulullah apakah kami juga mendapatkan pahala atas binatang yang kami ternak? Jawab beliau: iya. Sesungguhnya pada setiap makhluk hidup itu ada pahala. ${ }^{28}$

Hadits di atas menjelaskan bahwa seorang yang memberi minum seekor anjing yang kehausan adalah contoh sederhana cara berperilaku lemah lembut seseorang terhadap hewan. Hewan adalah makhluk yang Allah ciptakan sama halnya dengan manusia yang perlu dijaga dan dipenuhi kebutuhannya. Hewan dapat dimanfaatkan sebagai sumber penghasilan, membantu manusia dalam melaksanakan pekerjaan dan bahkan Sebagian hewan dapat dimanfaat sebagai makanan maka sepatutnya manusia menjaga perilaku lemah lembut terhadap hewan.

Mengabaikan sifat lemah lembut terhadap hewan bahkan cenderung menyiksanya merupakan sifat tercela yang bisa berakibat fatal bagi manusia itu sendiri. Hal ini sesuai dengan tuntunan nabi Muhammad shallahu alaihi wasallam dalam sebuah hadits:

${ }^{28}$ Imam Bukhari, Al-Jami' Ash-Shahih, juz:4, kitab Al-Adab, bab rahmatin nas wa albahaaim, hadits no: 6009, Hal:93. 


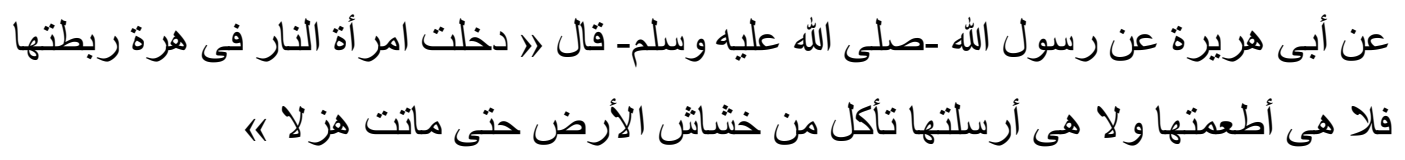

Artinya: Dari abu Hurairah dari rasul shallahu alaihi wasallam bersabda: seorang perempuan masuk neraka karena seekor kucing yang dia ikat tanpa memberinya makanan atau melepasnya agar dia bisa mencari serangga dari bumi sampai kucing tersebut mati. ${ }^{29}$

Hadits di atas menjelaskan bahwa sebab seseorang dimasukkan ke dalam neraka karena menyiksa, mengikat dan tidak memberi makan seekor kucing sehingga kucing tersebut mati dan tidak dapat mencari makanan sendiri. Allah swt menjamin rezeki makhluknya di darat maupun di laut dan mengilhamkan kepada mereka untuk mencari rezeki. Oleh karena itu, manusia tidak sepatutnya mengikat dan membatasi gerak hewan tersebut tanpa mencukupi hak dan kebutuhannya.

Sifat lemah lembut bersamaan dengan amal-amalan baik lainnya seperti berkurban atau sekedar menyembelih hewan. Terdapat cara cara bersikap lemah lembut dalam menyembelih binatang sebagaimana hadits nabi Muhammad shallahu alaihi wasallam:

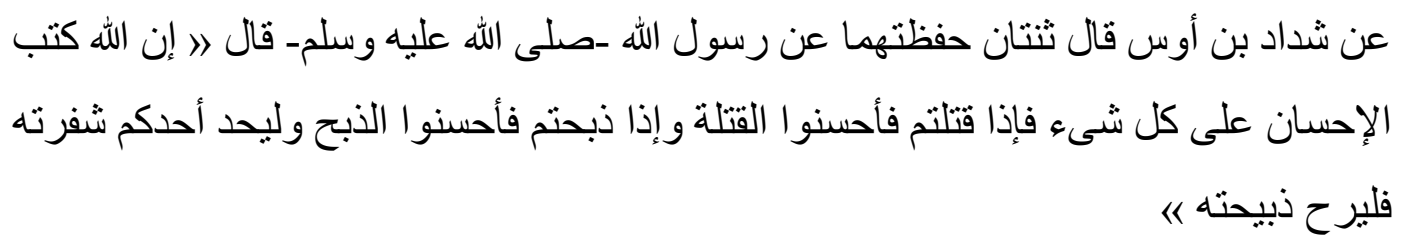

Artinya: Dari syaddad bin aus berkata: ada dua perkara yang aku ingat dari rasulullah shallahu alaihi wasallam, beliau bersabda: sesungguhnya Allah telah mewajibkan supaya selalu bersikap baik terhadap setiap sesuatu, jika kamu membunuh maka bunuhlah dengan cara yang baik. Jika kamu menyembelih maka sembelihlah dengan baik, tajamkan pisaumu dan senangkanlah hewan sembelihanmu. ${ }^{30}$

Hadits di atas menegaskan bahwa Allah tidak membedakan kewajiban berbuat baik dalam kegiatan apa saja, termasuk dalam menyembelih hewan. Hewan memiliki naluri sama halnya dengan manusia yang juga tidak ingin disakiti. Proses penyembelihan hewan hendaknya dilakukan dengan cara yang lembut dan

${ }^{29}$ Imam Muslim, Shahih Muslim, kitab taubah, bab fi si'ti rahmatillah ta'ala..., juz 2, hadits No. 2619, hal. 1263.

${ }^{30}$ Imam Muslim, Shahih Muslim, kitab Ash-shaidu wa az-zabaih..., juz 2, hadits No. 1955, hal. 940 . 
membuat hewan tersebut nyaman tanpa menakutinya. Allah SWT. Menginginkan terciptanya perilaku lemah lembut pada semua sisi kehidupan.

\section{KESIMPULAN}

Berdasarkan uraian pada pembahasan, maka dapat disimpulkan bahwa sifat lemah lembut menjadi kunci dasar terpujinya sikap seorang muslim baik dalam bertutur sapa atau dalam bertindak. Sifat lemah lembut mendatangkan pahala dan kebaikan dalam setiap perbuatan. Sifat lemah lembut tidak terbatas kepada manusia bahwa kepada seluruh makhluk hidup termasuk hewan. Mengabaikan sifat lemah lembut adalah sifat tercela yang akan mendatangkan kerugian, keputusan yang keliru, menimbulkan sakit hati, marah, dendam dan perpecahan.

Sifat lemah lembut memiliki ruang lingkup kajian yang luas. Dalam artikel ini hanya membahasa tentang lemah lembut kepada sesama manusia meskipun kepada orang yang berbuat kesalahan dan lemah lembut kepada hewan. Oleh karena itu, disarankan kepada penulis selanjutnya agar dapat membahas dan mengkaji pada ruang lingkup lain dari sifat lemah lembut.

\section{DAFTAR PUSTAKA}

\section{Al-Quranul Karim}

Abdul Karim Al-Qusyairi. Syarah Asmaul Husna. Bairut: Darul Azal, 1987.

Abu Daud. Sunan Abu Daud. Bairut: Dar Ibnu Hazam, 1998.

An-Nawawi, Syarah Shahih Muslim. Kairo: Maktabah Shafa, 2003.

Bahrisy, Ahmad. Konsep Kelembutan Dakwah dalam Al-Quran, 2018. Undergraduate thesis, UIN Sunan Ampel Surabaya.

Bahtar, Bahtar. "Komunikasi Anti Kekerasan: Membangun Budaya Damai dalam Perspektif Etika Komunikasi Islam." Al-Mishbah: Jurnal Ilmu Dakwah dan Komunikasi 9, no. 1 (2015).

Elly, M. Setiadi, dkk., Ilmu sosial dan Budaya Dasar. Jakarta: Kencana Penanda Media Group, 2007.

Ibnu Hajar Al-Asqalaqi, Fathul Baari. Riyadh: Darul Thayyibah, 2005.

Imam Bukhari, Al-Jami' Ash-Shahih. Kairo: Maktabah Salafiah, 1400H.

Imam Muslim, Al-Musnad As-shahih. Riyadh: Darul Thayyibah, 2006. 
Malla, Hamlan Andi Baso. "Implementation Of Madrasah Head Leadership Communication In The Development Of Religious Characters." AlMishbah: Jurnal Ilmu Dakwah dan Komunikasi 15, no. 2 (2020): 147-162.

Muhammad Bin Abi Bakri Bin Abdul Qadir Ar-Razi, Mukhtarus Shihah. Bairut: Maktabat Lubnan, 1989.

Mujahidah, Mujahidah. Urgensi Komunikasi Dalam Kelompok. Al-Mishbah: Jurnal Ilmu Dakwah dan Komunikasi, 8, no. 2 (2012).

Muslimah, Muslimah. "Etika Komunikasi dalam Persfektif Islam." Sosial Budaya 13, no. 2 (2017).

Nana Syaodih Sukmadinata, Metode Penelitian Pendidikan. Bandung: Remaja Rosdakarya, 2007.

Onong Uchjana Efendi. Dinamika Komunikasi. Bandung: Remaja Rosdakarya, 1992.

Sarjono. DD., Panduan Penulisan Skripsi. Yogyakarta: Jurusan Pendidikan Agama Islam, 2008.

Suharto, Suharto. "Komunikasi Dakwah: Interaksi Dan Integrasi Media Sosial." AlMishbah: Jurnal Ilmu Dakwah dan Komunikasi 9, no. 1 (2013).

Tim Dosen Pendidikan Agama Islam Universitas Lampung, Pendidikan Agama Islam Berbasis Karakter Di Perguruan Tinggi. Jakarta: Rajawali Pres, 2014. 